\title{
Прогноз изменения пьезометрической поверхности метегеро-ичерского водоносного комплекса подземного рудника «Интернациональный» (Якутия)
}

\author{
(С2021 Л. А. Еланцева ${ }^{1}$, С. В. Фоменко ${ }^{2 凶}$ \\ ${ }^{I}$ Белгородский государственный национальный исследовательский университет \\ (НИУ «БелГУ»), ул. Победы, 85, 308015, Белгород, Российская Федерация \\ ${ }^{2}$ Научно-технический и экспертный центр новых экотехнологий \\ в гидрогеологии и гидротехнике (НТЦ «НОВОТЭК»), пр. Б. Хмельницкого, \\ д. 131, 308002, Белгород, Российская Федерация
}

\begin{abstract}
Аннотация
Введение: Для восполнения выбывающих мощностей рудника «Интернациональный» планируется отработка подкарьерных запасов под защитой сооруженного искусственного и предохранительных целиков. На безопасность подземных горных работ ниже дна карьера оказывает непосредственное влияние напорный метегеро-ичерский водоносный комплекс (МИВК) и растворимые породы нижележащей толщи. Это требует разработки системы водозащиты рудника с учетом особенностей геологического строения и гидрогеологических условий трубки «Интернациональная». Рассматривались поверхностный, подземный и комбинированный способы водозащиты рудника. Основная цель исследований заключается в изучении положения уровней метегеро-ичерского водоносного комплекса после начала эксплуатации систем опережающего водопонижения на месторождении.

Memoduка: С использованием метода численного моделирования по программе MODFLOW системы GMS выполнено исследование различных вариантов систем осушения на плановой модели при напорно-безнапорном режиме фильтрации МИВК. Метегеро-ичерский водоносный комплекс в плане принят кусочно-однородным, в разрезе схематизировался как единый водоносный пласт с осредненными коэффициентами фильтрации. Прогнозы проводились в условиях обратной закачки рассолов рудника «Интернациональный» в структуру Западного разлома. При этом дебит обратной закачки принимался равным притоку к дренажным скважинам.

Результаты и обсуждение: Установлено, что поверхностный способ осушения водопонижающими скважинами не обеспечивает полного осушения МИВК в районе рудного тела, снятие остаточных уровней возможно восстающими дренажными скважинами с горизонта -145 м. Выявлено, что осушение МИВК из подземных горных выработок горизонтов $+85, \pm 0$ и -145 м целесообразно проводить в три этапа: сработка статических запасов МИВК с горизонта \pm 0 м напорными нисходящими дренажными скважинами; осушение МИВК безнапорными нисходящими дренажными скважинами с горизонта +85 м; снятие остаточных напоров восстающими дренажными скважинами с горизонта -145 м. Определено, что осушение рудника практически до подошвы МИВК обеспечивается эксплуатацией дренажных наклонно-восстающих скважин, сооружаемых из дренажного штрека горизонта -145 м. Заключение: По результатам прогнозного моделирования по всем исследуемым вариантам установлено снижение уровня подземных вод на участке ведения горных работ практически до подошвы МИВК. На основании многовариантных технико-экономических и гидрогеологических расчетов определена целесообразность принятого на месторождении подземного способа защиты рудника от дренажных рассолов, предусматривающего сооружение кольцевого дренажного штрека на горизонте 145 м с наклонными восстающими скважинами.
\end{abstract}

Контент доступен под лицензией Creative Commons Attribution 4.0 License.

\footnotetext{
Фоменко Сергей Викторович, e-mail: SVFomenko@rambler.ru
} 
Ключевые слова: рудник «Интернациональный», дренажные рассолы, метегеро-ичерский водоносный комплекс, дренажный штрек, дренажные скважины, моделирование

Для циитирования: Еланцева Л. А., Фоменко С. В. Прогноз изменения пьезометрической поверхности метегеро-ичерского водоносного комплекса подземного рудника «Интернациональный» (Якутия) // Вестник Воронежского государственного университета. Серия: Геология. 2021. №.2. С. 94-102.

DOI: https://doi.org/10.17308/geology.2021.2/3492

\section{Введение}

После окончания открытых горных работ на отметке +85 м абс. на дне карьера «Интернациональный» сооружен искусственный целик, предназначенный для защиты подземных горных работ от внешнего воздействия, включая камнепады и осыпи с бортов карьера и атмосферные осадки, концентрируемые на дне карьера, и представляющий собой железобетонную плиту, покрытую противофильтрационным экраном. Отвод поверхностного стока, попадающего на забой карьера, осуществляется через водоотливную штольню.

ИПКОН РАН обоснованы размеры предохранительных целиков. При отработке запасов над кровлей несдренированного 8-го коллектора МИВК мощность опасной зоны при проведении подготовительных выработок составляет $10 \mathrm{M}$, а при ведении очистных работ - 20 м. Для условий проходки вскрывающих и подготовительных выработок граница опасной зоны находится на отметке -25 м абс., при ведении очистных работ в подкарьерном блоке - на отметке -15 м абс.

Для условий ведения горных работ под несдренированным метегеро-ичерским водоносным комплексом граница опасной зоны при проведении одиночной закрепленной выработки располагается на расстоянии 20 м ниже почвы 8-го коллектора при проведении одиночных выработок с опережающим бурением и 30 м без опережающего бурения, т. е. на абсолютных отметках -117 м и -127 м.

Граница опасной зоны ниже несдренированного 8го коллектора МИВК при ведении очистных работ определена исходя из параметров свода обрушения, формирующегося под влиянием ранее накопленных недозакладов при выемке нижележащих блоков. При условии накопленной мощности недозакладов в пределах выемочного блока 2 м граница опасной зоны должна быть установлена на отметке -142 м абс. при условии разработки мероприятий по контролю и ликвидации сверхнормативных недозакладов. В случае если эффективная мощность недозакладов окажется меньше принятой в расчете величины, высота опасной зоны может быть уменьшена при условии учета уже произошедших деформаций и обрушений.

Под защитой предохранительных целиков планируется осуществлять подземную отработку подкарьерных запасов в интервале отметок, распространенных от дна карьера до отработанных запасов, т.е. от
+85 до -150 м.

Сложность отработки рудного тела обусловлена нахождением подкарьерных запасов в зоне влияния высоконапорного метегеро-ичерского водоносного комплекса и наличия растворимых пород в нижележащей чарской толще.

Защита подземных горных выработок от подземных вод МИВК является весьма актуальной задачей, связанной с отработкой полезного ископаемого ниже дна карьера.

При разработке решений по водозащите рудника от подземных вод МИВК учитывались особенности геологического строения и гидрогеологических условий месторождения [1-5]:

- наличие в разрезе мощной толщи терригенных, терригенно-карбонатных и галогенно-сульфатно-карбонатных кембрийских отложений, прорванных вертикально стоящим рудным телом;

- фильтрационные свойства водовмещающих пород неоднородны и анизотропны в плане и разрезе, тектонические нарушения могут являться как барражами, так и зонами повышенной водопроницаемости и обводненности;

- метегеро-ический водоносный комплекс залегает в интервале глубин 340-530 м, характеризуется мощностью 170-180 м и напором над кровлей более 100 м. В разрезе МИВК выделено 9 пластов-коллекторов, из которых наибольшей водопроводимостью обладает 8й пласт-коллектор, играющий превалирующую роль в обводнении месторождения. По химическому составу подземные воды МИВК представляют собой сероводородные хлоридные натриевые рассолы с минерализацией от 95 до 300 г/л и отрицательной температурой до $-2^{\circ} \mathrm{C}$, содержат растворенные природные газы (газовый фактор от 0.01 до $0.25 \mathrm{~m}^{3} / \mathrm{M}^{3}$ ). Концентрация сероводорода составляет 120-130 мг/л;

- залегающие под подошвой МИВК засоленные долериты, галогенно-карбонатные отложения чарской свиты, а также рудное тело относятся к слабопроницаемым породам.

\section{Методика исследований}

ООО НТЦ «НОВОТЭК» рассматривал варианты защиты рудника «Интернациональный» от подземных вод МИВК поверхностным, подземным и комбинированным способом.

Численный метод моделирования является основным методом решения задач по исследованию процесса фильтрации подземных вод с целью защиты горных выработок от подземных вод [6-16].

Гидрогеологические исследования способов защиты рудника от рассолов выполнены с помощью математического моделирования, которое проводилось на плановой модели в условиях напорно-безнапорного режима фильтрации метегеро-ичерского водоносного комплекса.

Метегеро-ичерский водоносный комплекс из-за изменчивости фильтрационных свойств в плане принят кусочно-однородным, в разрезе схематизировался как 
единый водоносный пласт с осредненными коэффициентами фильтрации.

Моделирование осуществлялось по программе MODFLOW лицензионного пакета GMS, которая реализует методом конечных разностей пространственную фильтрацию подземных вод в многослойной толще.

Помимо площадных кусочно-однородных зон на численной модели отражены элементы неоднородности в виде «тонких» структур: разломы и искусственно создаваемые противофильтрационные элементы, задаваемые на модели фильтрационными барьерами в виде $c=k / b$, где $k-$ коэффициент фильтрации структуры; $b$ - ширина структуры.

Прогноз изменения гидродинамического режима подземных вод при эксплуатации дренажного комплекса рудника «Интернациональный» выполнен в соответствии с графиком вскрытия, подготовки и отработки подкарьерных запасов при закачке дренажных рассолов на узле закачки вод в структуру Западного разлома с учетом их возврата к дренажному контуру рудника.

Условия разгрузки подземного потока дренажными устройствами подземного дренажного контура рудника «Интернациональный» при отработке подкарьерных запасов реализованы на модели в виде постепенного снижения пьезометрического уровня подземных вод МИВК с +200 до -130 м абс.

Дебит обратной закачки дренажных рассолов рудника «Интернациональный» принимался равным притоку к ПДК, для чего использовалась итерационная процедура, которая завершалась при равенстве дебитов откачки и закачки. Закачка дренажных вод осуществлялась в линейный ряд скважин, расположенных за Западным разломом. В каждую скважину закачивалось до $100 \mathrm{~m}^{3} /$ ч $\left(2400 \mathrm{~m}^{3} /\right.$ сут) дренажных рассолов, т.е. приемистость скважины принималась равной $100 \mathrm{~m}^{3} / \mathrm{ч}$.

\section{Результаты исследований}

Поверхностный способ осушения предполагает сооружение системы водопонижающих скважин (ВПС) с поверхности на расстоянии более 50 м от контура карьера. Глубина скважин составит 510 м, общее количество скважин - 28 шт. Скважины равномерно распределяются по периметру карьера. Расчетный дебит всех ВПС, при котором уровень МИВК опустится до подошвы 8-го коллектора, составит $1200 \mathrm{~m}^{3} /$ ч.

Прогнозное положение уровней МИВК при эксплуатации ВПС представлено на рисунке 1.

Следует отметить, что из опыта эксплуатации системы водопонижающих скважин на карьере «Мир» перед сооружением ВПС вытекает необходимость выделения с помощью контрольно-разведочного бурения наиболее водообильных зон водоносного комплекса, обладающего неоднородными фильтрационными свойствами водовмещающих пород в разрезе и плане. Размещение скважин на поверхности осложняется ситуационной обстановкой: наличием отвалов, сооружений промплощадки и т. п.
ВПС с поверхности не обеспечивают полного осушения МИВК в районе рудного тела. Для снятия остаточных уровней предусматривается сооружение восстающих дренажных скважин с горизонта -145 м, которые располагаются равномерно вокруг рудного тела по трассе кольцевого дренажного штрека. Суммарный приток из восстающих дренажных скважин составит $60 \mathrm{~m}^{3} /$. Таким образом, общий водоприток при работе ВПС и восстающих дренажных скважин оценивается величиной $1260 \mathrm{~m}^{3} /$ ч.

На основании многовариантных технико-экономических и гидрогеологических расчетов принят подземный способ осушения, позволяющий максимально приблизить систему осушения к защищаемым участкам ведения горных работ, достичь наибольшего эффекта опережающего водопонижения, регулировать водоприток к дренажной системе, обеспечить организованный сбор, отвод и закачку откачиваемых рассолов, практически исключить климатический фактор при эксплуатации дренажной системы.

Кроме того, анализ многолетнего опыта эксплуатации дренажных систем на других месторождениях свидетельствует о весьма высокой эффективности подземного способа осушения в условиях рудника.

Рассматривалось осушение МИВК из подземных горных выработок горизонтов $+85, \pm 0$ и -145 м.

Срабатывание статических запасов МИВК осуществляется с горизонта \pm 0 м с помощью напорных нисходящих дренажных скважин, сооружаемых по кольцу вокруг рудного тела.

С целью уменьшения объемов горнопроходческих работ рассмотрен вариант одностороннего расположения дренажных скважин (полукольцо).

Дальнейшее осушение МИВК выполняется безнапорными нисходящими дренажными скважинами с горизонта +85 м.

Результаты моделирования показывают, что эксплуатация нисходящих дренажных скважин с горизонта +85 м не обеспечивает полного осушения МИВК в районе рудного тела. Для снятия остаточных уровней необходимо сооружение восстающих дренажных скважин, равномерно располагаемых вокруг рудного тела по трассе кольцевого дренажного штрека горизонта -145 м.

Прогнозное положение уровней МИВК при работе дренажных скважин на горизонтах $\pm 0,+85$ и -145 м представлено на рисунке 2, результаты прогнозного моделирования приведены в таблице.

Подземный способ осушения с горизонта -145 м предусматривает проходку под защитой предохранительного целика специальной кольцевой дренажной выработки (дренажного штрека) протяженностью около 760 м в слабопроницаемой толще гипсо-ангидритов и доломитов на отметке -145 м и сооружение из выработки наклонно-восстающих скважин. С целью обеспечения вскрытия наиболее обводненного 8-го коллектора длина восстающих скважин должна быть порядка 90 м. Дренажные скважины равномерно располагаются по штреку. 




Рис. 1. Прогнозное положение уровней МИВК при работе ВПС.

[Fig. 1. Forecast position of the water levels in the MIXAS during the operation of drainage wells.]

Табл. Основные показатели эксплуатации дренажных скважин

[Table. Main indicators of the drainage well's operation]

\begin{tabular}{|c|c|c|c|c|}
\hline \multirow{3}{*}{$\begin{array}{l}\text { Показатели } \\
\text { [Indicators] }\end{array}$} & \multicolumn{4}{|c|}{$\begin{array}{c}\text { Расположение контура дренажных скважин } \\
\text { [Location of the drainage wells contour] }\end{array}$} \\
\hline & \multicolumn{2}{|c|}{$\begin{array}{c}\text { гор. } \pm 0 \mathrm{M} \\
{[\text { horizon } \pm 0 \mathrm{~m}]}\end{array}$} & \multirow{2}{*}{$\begin{array}{c}\text { гор. }+85 \mathrm{~m} \\
{[\text { horizon } \pm 85 \mathrm{~m}]}\end{array}$} & \multirow{2}{*}{$\begin{array}{c}\text { гор. }+85 \text { м и }-145 \\
\text { м } \\
\text { [horizons }+85 \mathrm{~m} \\
\text { and }-145 \mathrm{~m}]\end{array}$} \\
\hline & $\begin{array}{c}\text { кольцо } \\
\text { [ring] }\end{array}$ & $\begin{array}{c}\text { полукольцо } \\
\text { [half ring] }\end{array}$ & & \\
\hline $\begin{array}{l}\text { Количество скважин, шт. } \\
\text { [Number of wells, pcs.] }\end{array}$ & 9 & 9 & 14 & 29 \\
\hline $\begin{array}{l}\text { Протяженность дренажного штрека, м } \\
\text { [The length of drainage roadway, m] }\end{array}$ & 450 & 215 & 630 & $630 / 760$ \\
\hline $\begin{array}{l}\text { Уровень МИВК в скважинах, м } \\
\text { [Water level of the Metegero-Ichersky aqui- } \\
\text { fer system inside wells, m] }\end{array}$ & \pm 0 & $20-40$ & -90 & -143 \\
\hline $\begin{array}{l}\text { Водоприток к скважинам, м } 3 / \text { ч } \\
\text { [Water inflow to wells, } \mathrm{m}^{3} / \mathrm{h} \text { ] }\end{array}$ & 600 & 540 & 850 & 910 \\
\hline
\end{tabular}




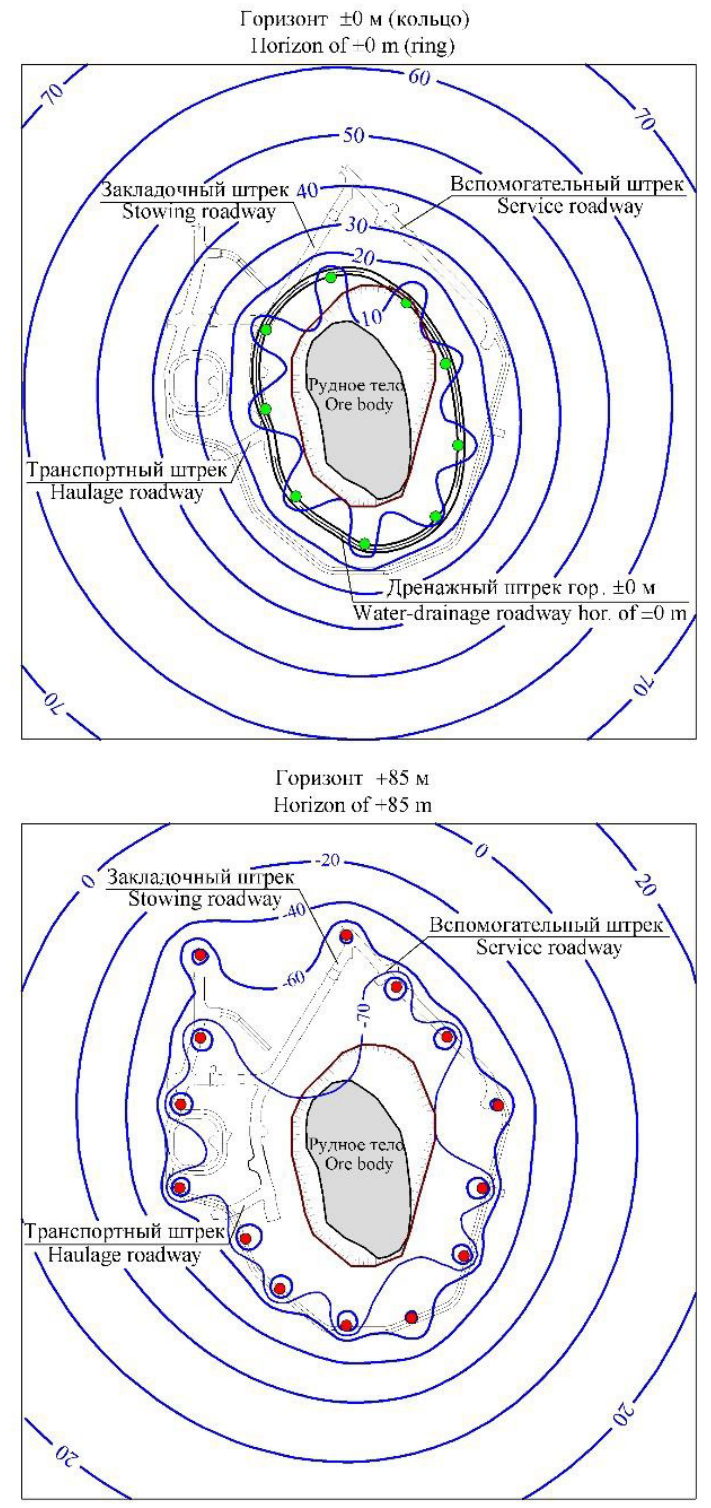

Дренажные скважины [Drainage wells]

-

$\circ$

-
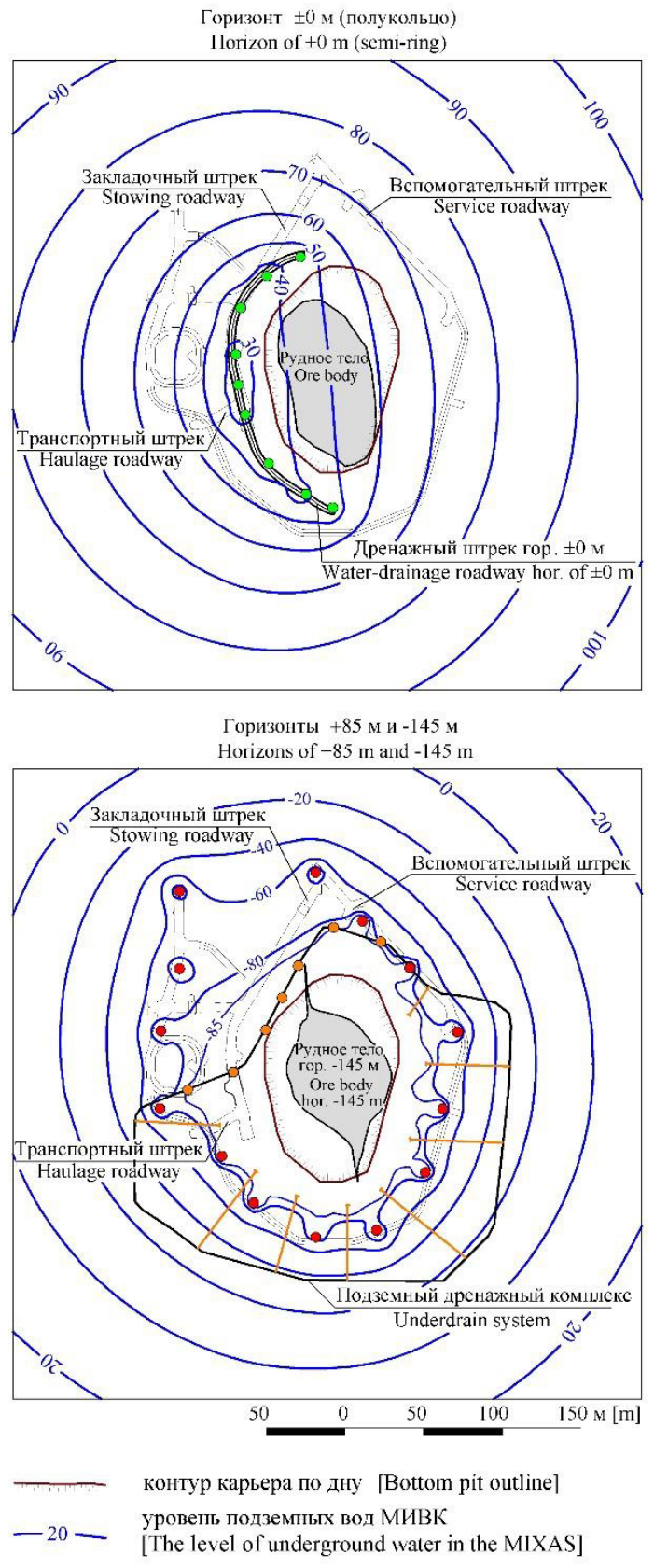

Рис. 2. Прогнозное положение уровней МИВК при работе дренажных скважин, расположенных на гор. \pm 0 м, $+85 \mathrm{M},+85$ и $-145 \mathrm{~m}$.

[Fig. 2. Forecast position of the water levels in the MIXAS during the operation of drainage wells located at the horizons of $\pm 0 \mathrm{~m},+85 \mathrm{~m}$, and $-145 \mathrm{~m}$.]

Общий объем дренажных вод по замкнутой системе водоотведения поступает в коллектор насосной станции и откачивается на поверхность с горизонта 145 м и направляется для складирования на узел закачки вод (УЗВ) за Западным разломом.

В настоящее время на горизонте -145 м построены основные элементы подземного дренажного комплекса: кольцевой штрек, комплекс подземного водоотлива, система водоотведения с водоводами и водоотливными скважинами, но не сооружена система наклонно-восстающих дренажных скважин из подземных выработок кольцевого штрека во вмещающие породы.

В 2012 г. проводились расчеты, касающиеся режима водопонижения в МИВК при одновременной эксплуатации ПДК рудника «Интернациональный» и карьера «Мир» в штатном режиме: откачка из карьера в объеме $1250 \mathrm{~m}^{3} /$ ч и обратная закачка рассолов на СО3 за Восточным разломом в количестве 1350 м³/ч [17].

Согласно расчетам водоприток из метегеро-ичерского водоносного комплекса к ПДК рудника «Интернациональный» составит $900 \mathrm{~m}^{3} /$, из которых $60 \mathrm{~m}^{3} / \mathrm{ч}$ приходится на проскок подземных вод через дренаж- 
ный контур. Водозащита от рассолов МИВК предусматривалась сооружением из дренажного штрека 23 дренажных узлов по 3-5 наклонно-восстающих скважин в каждом. Водоприток к одному дренажному узлу не превысит $50 \mathrm{~m}^{3} /$.

В современных условиях прогнозное моделирование выполнялось в условиях затопления карьера «Мир» до отметки +75 м и отсутствия утилизации рассолов в МИВК на СО3 за Восточным разломом. Затопление карьера выше отметки +75 м приведет к значительному снижению устойчивости бортов карьера и повышению риска масштабных обрушений.

Результаты прогнозного моделирования показывают, что водоприток к ПДК рудника «Интернациональный» составит порядка $1000 \mathrm{~m}^{3} /$ ч, из которых 970 $\mathrm{m}^{3} / \mathrm{ч}$ - это приток к дренажным наклонно-восстающим скважинам и $30 \mathrm{~m}^{3} / \mathrm{ч}$ - проскок подземных вод через контур дренажных скважин. Водоприток к карьеру «Мир» не превысит $380 \mathrm{~m}^{3} /$.

Осушение обеспечивалось работой 60 дренажных наклонно-восстающих скважин, равномерно располагаемых по штреку с шагом 10-15 м под углом заложения 55-60 по направлению движения. При этом достигалось снижение уровня подземных вод на участке ведения горных работ практически до подошвы МИВК (-130 м). Водоприток к одной восстающей скважине составит $10-25 \mathrm{~m}^{3} /$ ч. По мере снижения уровня в водоносном комплексе приток рассолов к одной восстающей скважине будет постепенно уменьшаться, а также будет снижаться уровень подземных вод МИВК.

Прогнозное распределение уровня подземных вод метегеро-ичерского водоносного комплекса при отработке подкарьерных запасов приводится на рисунках 3-4.

Таким образом, водоприток из метегеро-ичерского водоносного комплекса к ПДК рудника «Интернациональный» при затоплении карьера «Мир» по сравнению с вариантом одновременной эксплуатацией ПДК рудника «Интернациональный» и карьера «Мир» увеличится на $100 \mathrm{~m}^{3} /$ ч или на $11 \%$.

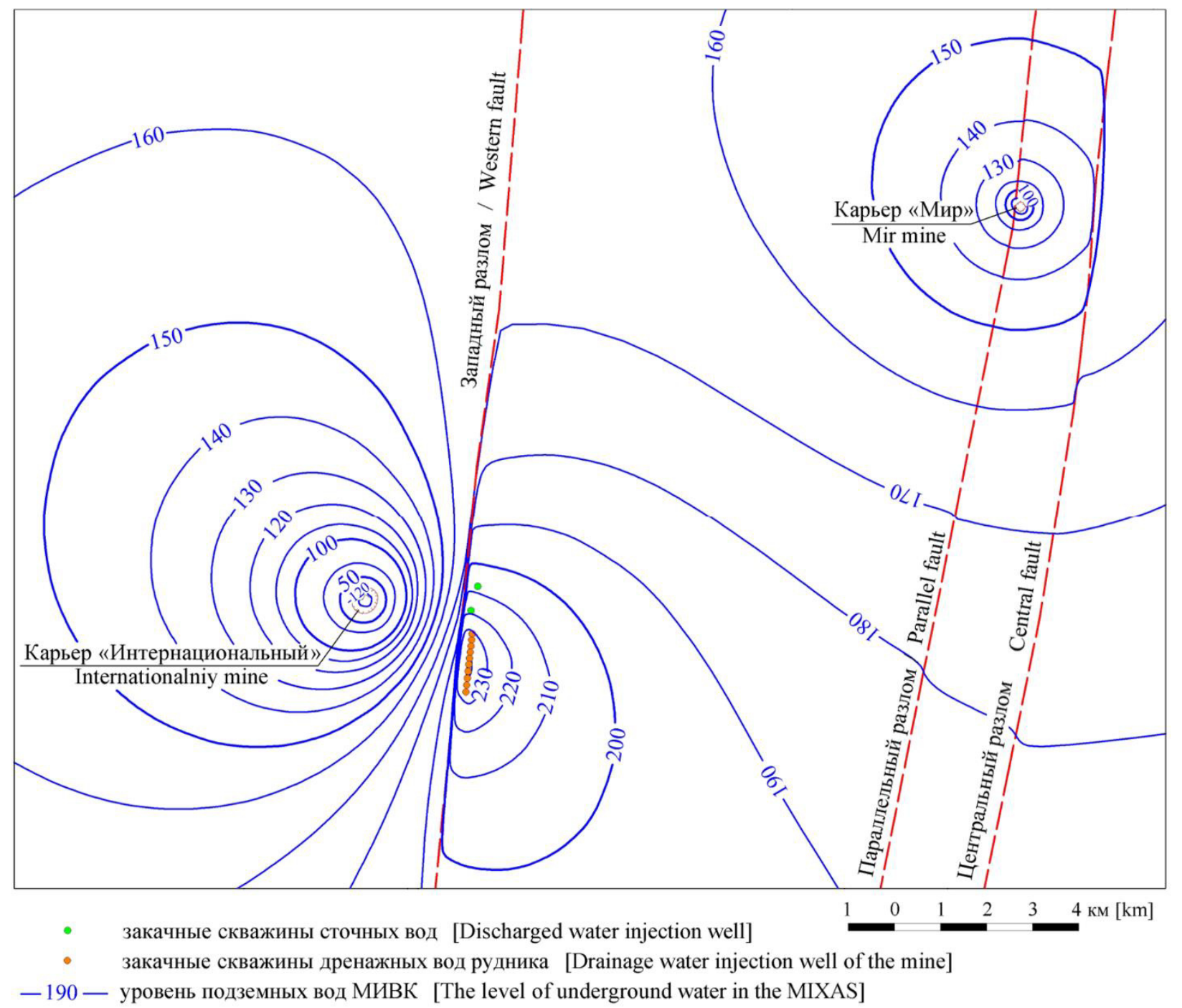

Рис. 3. Прогнозное распределение уровня подземных вод метегеро-ичерского водоносного комплекса.

[Fig. 3. Forecast distribution of the groundwater level in the Metegero-Ichersky aquifer system.] 


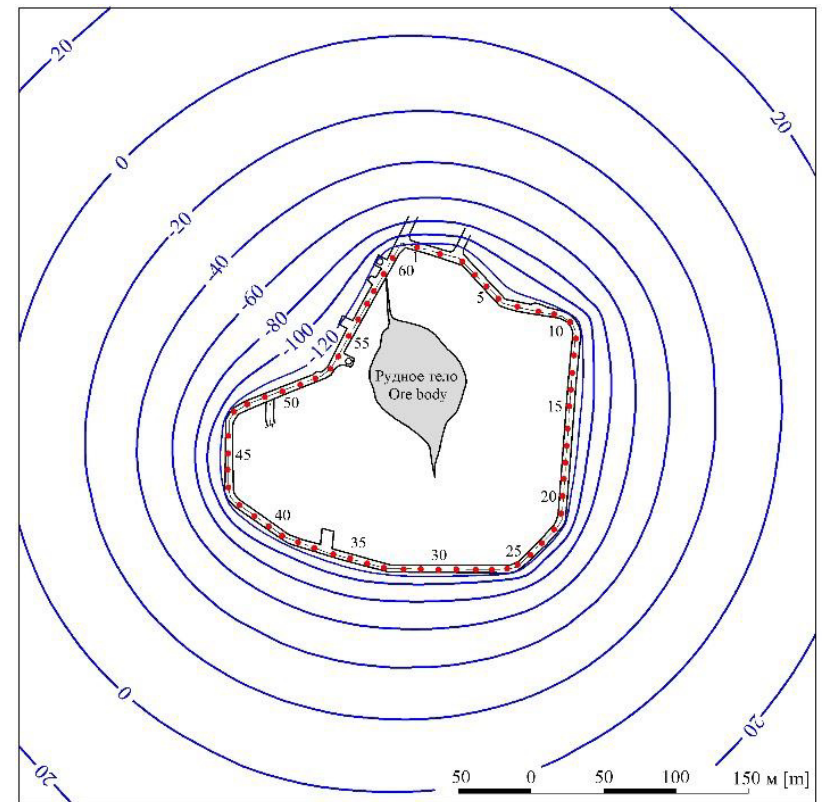

Рис. 4. Прогнозное распределение уровней подземных вод метегеро-ичерского водоносного комплекса в зоне кольцевого дренажного штрека.

[Fig. 4. Forecast distribution of the groundwater level in the Metegero-Ichersky aquifer system in the area of annular waterdrainage roadway.]

\section{Заключение}

ООО НТЦ «НОВОТЭК» рассматривал поверхностный, подземный и комбинированный способы водозащиты рудника «Интернациональный» от подземных вод МИВК.

Эксплуатация 28 ВПС не обеспечивает полного осушения МИВК на участках ведения горных работ. Остаточные уровни необходимо снимать 15 восстающими дренажными скважинами, пробуренными с горизонта -145 м по трассе дренажного штрека.

Следует отметить, что МИВК обладает неоднородными фильтрационными свойствами в плане и разрезе, что потребует предварительного выделения водообильных зон с помощью контрольно-разведочного бурения.

Осушение МИВК из подземных горных выработок горизонтов $+85, \pm 0$ и -145 м требует сооружения дренажных скважин в три этапа: 9 напорными нисходящими дренажными скважинами с горизонта \pm 0 м осуществляется сработка статических запасов МИВК; 14 безнапорными нисходящими дренажными скважинами с горизонта +85 м - дальнейшее осушение МИВК; 15 восстающими дренажными скважинами с горизонта -145 м - снятие остаточных напоров.

Многовариантные технико-экономические и гидрогеологические расчеты позволили принять на месторождении подземный способ защиты рудника от рассолов, предусматривающий сооружение кольцевого дренажного штрека на горизонте -145 м с 60 наклонными восстающими скважинами. Перспективность варианта объясняется тем, что на горизонте -145 м построены кольцевой штрек, комплекс подземного водо- отлива, система водоотведения с водоводами и водоотливными скважинами, не сооружена только система наклонно-восстающих дренажных скважин из подземных выработок кольцевого штрека.

По результатам прогнозного моделирования по всем исследуемым вариантам снижение уровня подземных вод на участке ведения горных работ ожидается практически до подошвы МИВК.

Конфликт интересов: Авторы декларируют отсутствие явных и потенциальных конфликтов интересов, связанных с публикацией настоящей статьи.

\section{ЛИТЕРАТУРА}

1. Харькив А. Д., Зинчук Н. Н., Крючков А. И. Коренные месторождения алмазов мира. М.: Недра, 1998. 555 с.

2. Дроздов А. В., Иост Н. А., Лобанов В. В. Криогидрогеология алмазных месторождений Западной Якутии. Иркутск: ИГТУ, 2008. $507 \mathrm{c}$.

3. Алексеев С. В. Криогидрогеологические системы Якутской алмазоносной провинции. Новосибирск: ГЕО, 2009. 319 с.

4. Колганов В. Ф., Агишев А. Н., Дроздов А. В. Геолого-гидрогеологические особенности коренных месторождений алмазов Якутии. Мирный: Якутнипроалмаз, 2013. 568 с.

5. Костровицкий С. И., Специус 3. В., Яковлев Д. А., Фон-дер Флаасс Г.С., Суворова Л. Ф., Богуш И. Н. Атлас коренных месторождений алмазов Якутской кимберлитовой провинции. Мирный: МГТ, 2015. 480 с.

6. Лукнер Л., Шестаков В. М. Моделирование геофильтрации. М.: Недра, 1976. 407 с.

7. Ломакин Е. А., Мироненко В. А., Шестаков В. М. Численное моделирование геофильтрации. М.: Недра, 1988. 228 с.

8. Xing Zhang, David J. Sanderson. Numerical Modelling and Analysis of Fluid Flow and Deformation of Fractured Rock Masses. London, UK., PERGAMON An Imprint of Elsevier Science. Imperial College of Science, Technology and Medicine University of London, 2002. $288 \mathrm{p}$.

9. Szymkiewicz A. Modelling Water Flow in Unsaturated Porous Media: Accounting for Nonlinear Permeability and Material Heterogeneity, 2014. $237 \mathrm{p}$.

10. Su Y., Davidson J.H. Modeling Approaches to Natural Convection in Porous Media. Cham; Heidelberg; New York; Dordrecht; London, Springer, X, 2015. $47 \mathrm{p}$.

11. Anderson M. P., Woessner W. W. In Applied Groundwater Modeling. San Diego: Academic Press, 2015. 564 p.

12. Aly I. El-Kadi. Groundwater Models for Resources Analysis and Management. N.W., Boca Raton, FL: lewis publishers is an imprint of CRC Press, 2017. 384 p.

13. Alain Dassargues. Hydrogeology: Groundwater Science and Engineering. N.W., Boca Raton, FL: CRC Press Taylor \& Francis Group, 2018. 472 p.

14. Аузина Л. И. Динамика подземных вод. Иркутск: Издательство ИРНИТУ, 2019. $113 \mathrm{c.}$

15. Гриневский С. О. Гидрогеодинамическое моделирование взаимодействия подземных и поверхностных вод. М.: Инфра-М, 2020. 153 c.

16. Стадник Д. А., Курцев Б. В., Кузнецов Ю. Н., Стадник Н. М. Методическое руководство по цифровому трехмерному моделированию георесурсного потенциала пластовых месторождений полезных ископаемых. М.: Горная книга, 2021. 224 с.

17. Еланцева Л. А., Фоменко С. В. Исследование управляемого водопонижения и утилизации дренажных рассолов рудника «Интернациональный» при отработке подкарьерных запасов. Геология и минерально-сырьевые ресурсы Северо-востока России: материалы VII Всероссийской научно-практической конференции. Якутск: Издательский дом СВФУ, 5-7 апреля 2017. Том II. C. $318-322$. 
UDC 556.3-662.5

ISSN 1609-0691

DOI: https://doi.org/10.17308/geology.2021.2/3492

Received: 28.04 .2021

Accepted: 20.05.2021

Published online: 30.06 .2021

\title{
Forecast changes of the piezometric surface of the Metegero-Ichersky aquifer system in the Internationalniy mine (Yakutia)
}

\author{
C2021 L. A. Elantseva ${ }^{1}$, S. V. Fomenko ${ }^{2 区}$ \\ ${ }^{1}$ Belgorod State National Research University 85 Pobeda ul., Belgorod 308015, Russian Federation \\ ${ }^{2}$ Scientific and Technical Expert Centre for New Eco Technologies in Geohydrology and \\ Hydraulic Engineering, 131 Khmelnitskogo pr., Belgorod 308002, Russian Federation
}

\begin{abstract}
Introduction: To compensate for the retired capacities of the Internationalniy mine, it is planned to remove pit reserves under the protection of artificial pillar supports. The safety of underground mining below the bottom of the quarry is directly affected by the Metegero-Ichersky confined aquifer system (MIXAS) and soluble rocks in the underlying rock mass. This requires developing a waterproofing system in the mine considering the peculiarities of the geological structure and hydrogeological conditions of the Internationalniy diatreme. Superficial, underground, and combined waterproofing methods were considered. The main purpose of the research was to study the positions of the levels of the Metegero-Ichersky aquifer system after the advance dewatering systems started to operate in the field.

Methodology: By means of numerical modelling and the MODFLOW GMS program various alternatives of drainage systems were studied with the help of a planned model under pressure-pressureless filtration modes in the MIXAS. According to the plan, the Metegero-Ichersky aquifer system is assumed to be piecewise homogeneous, in the cross section it was presented as a single aquifer with averaged filter coefficients. The forecast was conducted under the conditions of reinjection of the brine from the Internationalniy mine into the structure of the Western fault. In this case, the reinjection flow rate was assumed to be equal to the inflow of drainage wells.

Results and discussion: It was found that the surface dewatering by means of drainage wells does not provide complete drainage of the MIXAS in the area of the ore body. The residual levels may be removed by up-holes from the horizon of $145 \mathrm{~m}$. It was revealed that it is reasonable to drain the MIXAS from the underground mine workings of the horizons of $+85, \pm 0$, and $-145 \mathrm{~m}$ in three stages: the dewatering of confined static reserves of the MIXAS from the horizon of $\pm 0 \mathrm{~m}$ by down-holes; the dewatering of the unconfined MIXAS by down-holes from the horizon of $+85 \mathrm{~m}$; the removal of residual water by up-holes from the horizon of $-145 \mathrm{~m}$. It was determined that the mine drainage almost to the bottom of the MIXAS is provided by the operation of inclined up-holes constructed from the drainage roadway at the horizon of $-145 \mathrm{~m}$.

Conclusions: According to the results of prediction modelling, all investigated alternatives will result in the decrease in the level of groundwater at the site of mining operations almost to the bottom of the MIXAS. Multivariate technical, economic, and hydrogeological calculations proved the practicability of the underground method of protecting the mine from brine which was adopted at the site and which involved constructing a ring water-drainage roadway and inclined up-holes at the horizon of $-145 \mathrm{~m}$.

Keywords: Internationalniy mine, drainage brines, Metegero-Ichersky aquifer system, drainage roadway, drainage wells, modelling.
\end{abstract}

The content is available under Creative Commons Attribution 4.0 License.

\footnotetext{
Sergey V. Fomenko, e-mail: SVFomenko@rambler.ru
} 
For citation: Elantseva L.A., Fomenko S.V. Forecast changes of the piezometric surface of the MetegeroIchersky aquifer system in the Internationalniy mine (Yakutia). Vestnik Voronezhskogo gosudarstvennogo universiteta. Seriya: Geologiya - Proceedings of Voronezh State University. Series: Geology, 2021, no. 2, pp. 94-102. DOI: https://doi.org/10.17308/geology.2021.2/3492

Conflict of interests: The authors declare the absence of obvious and potential conflicts of interest related to the publication of this article.

\section{REFERENCES}

1. Harkiv A. D., Zinchuk N. N., Kryuchkov A. I. Korennie mestorojdeniya almazov mira [Primary deposit diamonds of the world]. Moscow, Nedra Publ., 1998. 555 p. (in Russ.)

2. Drozdov A. V., Iost N. A., Lobanov V. V. Kriogidrogeologiya almaznykh mestorozhdenii Zapadnoi Yakutii [Cryohydrogeology of diamond deposits in Western Yakutia]. Irkutsk, ISTU Publ., 2008. 507 p. (in Russ.)

3. Alekseev S. V. Kriogidrogeologicheskie sistemy Yakutskoi almazonosnoi provintsii [Cryohydrogeological systems of the Yakut diamond-bearing province]. Novosibirsk, GEO Publ., 2009. 319 p. (in Russ.)

4. Kolganov V. F., Agishev A. N., Drozdov A. V. Geologo-gidrogeologicheskie osobennosti korennykh mestorozhdenii almazov Yakutii [Geological and hydrogeological features of the indigenous diamond deposits of Yakutia]. Mirny, Yakutniproalmaz Publ., 2013. 568 p. (in Russ.)

5. Kostrovickij S. I., Specius Z. V., Yakovlev D. A., Fon-der Flaass G.S., Suvorova L. F., Bogush I. N. Atlas korennykh mestorozhdenii almazov Yakutskoi kimberlitovoi provintsii [Atlas of indigenous diamond deposits of the Yakut kimberlite province]. Mirny, MCP Publ., 2015. 480 p. (in Russ.)

6. Lukner L., Shestakov V. M. Modelirovanie geofiltracii [Modeling of geofiltration]. Moscow, Nedra Publ., 1976. 407 p. (in Russ.)

7. Lomakin E. A., Mironenko V. A., Shestakov V. M. Chislennoe modelirovanie geofiltracii [Numerical modeling of geofiltration]. Moscow, Nedra Publ., 1988. 228 p. (in Russ.)

8. Xing Zhang, David J. Sanderson. Numerical Modelling and Analysis of Fluid Flow and Deformation of Fractured Rock
Masses. London, UK., PERGAMON An Imprint of Elsevier Science. Imperial College of Science, Technology and Medicine University of London, 2002. 288 p.

9. Szymkiewicz A. Modelling Water Flow in Unsaturated Porous Media: Accounting for Nonlinear Permeability and Material Heterogeneity, 2014. $237 \mathrm{p}$.

10. Su Y., Davidson J.H. Modeling Approaches to Natural Convection in Porous Media. Cham; Heidelberg; New York; Dordrecht; London, Springer, X, 2015. 47 p.

11. Anderson M. P., Woessner W. W. In Applied Groundwater Modeling. San Diego: Academic Press, 2015. 564 p.

12. Aly I. El-Kadi. Groundwater Models for Resources Analysis and Management. N.W., Boca Raton, FL: lewis publishers is an imprint of CRC Press, 2017. 384 p.

13. Alain Dassargues. Hydrogeology: Groundwater Science and Engineering. N.W., Boca Raton, FL: CRC Press Taylor \& Francis Group, 2018. 472 p.

14. Auzina L. I. Dinamika podzemnyh vod. [Dynamics of groundwater]. Irkutsk, INRTU Publ., 2019. 113 p. (in Russ.)

15. Grinevskii S. O. Gidrogeodinamicheskoe modelirovanie vzaimodejstviya podzemnyh i poverhnostnyh vod [Hydrogeodynamic modeling of interaction of underground and surface waters]. Moscow, Infra-M Publ., 2020. 153 p. (in Russ.)

16. Stadnik D. A., Kurcev B. V., Kuznecov YU. N., Stadnik N. M. Metodicheskoe rukovodstvo po tsifrovomu trekhmernomu modelirovaniyu georesursnogo potentsiala plastovykh mestorozhdenii poleznykh iskopaemykh. [Methodological guide to digital three-dimensional modeling of the geo-resource potential of formation mineral deposits.]. Moscow, Mountain Book Publ., 2021. 224 p. (in Russ.)

17. Elantseva L. A., Fomenko S. V. Issledovanie upravlyaemogo vodoponizheniya i utilizatsii drenazhnykh rassolov rudnika «Internatsional'nyi» pri otrabotke podkar'ernykh zapasov [Investigation of managed water reduction and utilization of drainage brines of the «Internacional'niy» mine when of pit reserves under the quarry]. Geologiya $i$ mineral'no-syr'evye resursy Severo-vostoka Rossii: materialy VII Vserossijskoj nauchno-prakticheskoj konferencii [Geology and mineral resources north-east Russia: materials of the VII All-Russian Scientific and Practical Conference], Yakutsk, NEFU Publishing House, April 5-7, 2017, p. 318-322. Available at: http://reportnir.s-vfu.ru/upload/5a39cfca81ba9.pdf (accessed 27 May 2021). (in Russ.)
Еланцева Людмила Алексеевна - к. г.-м. н., доцент, Белгородский государственный национальный исследовательский университет (НИУ «БелГУ»), Белгород, Российская Федерация; E-mail: Elantseva@bsu.edu.ru;

ORCID https://orcid.org/0000-0002-9954-1207

Фоменко Сергей Викторович - с. н. с. ООО НТЦ «НОВОТЭК», Белгород, Российская Федерация;

E-mail: SVFomenko@rambler.ru; ORCID https://orcid.org/0000-0003-3436-6468

Авторы прочитали и одобрили окончательный вариант рукописи.
Lyudmila A. Elanceva - PhD in Geol-Min., Associate Professor, Belgorod National Research University (NRU "BelSU"), Belgorod, Russian Federation;

E-mail: Elantseva@bsu.edu.ru;

ORCID https://orcid.org/0000-0002-9954-1207

Sergey V. Fomenko - senior research fellow OOO NTC NOVOTEK, Belgorod, Russian Federation;

E-mail: SVFomenko@rambler.ru;

ORCID https://orcid.org/0000-0003-3436-6468

All authors have read and approved the final manuscript. 